\title{
Length composition and abundance of eel larvae, Anguilla anguilla (Anguilliformes: Anguillidae), in the Iberian Basin (northeastern Atlantic) during July-September 1984
}

\author{
H.-D. Bast \& B. Strehlow \\ Sektion Biologie, Universität Rostock; Universitätsplatz 5, D-O-2500 Rostock, Germany
}

\begin{abstract}
Anguilla anguilla (L., 1758) from the Iberian Basin were analysed. The observed horizontal trends of abundance and particularly the mean sizes contradict the expectations based on the hypothesis of larvae distribution exclusively by drift with Gulf and North Atlantic Currents, and support the hypothesis of an active larval migration also south of the Azores.
\end{abstract}

\section{INTRODUCTION}

During the period July-September 1984, investigations of the epi- and mesopelagic fish resources of the Iberian basin (outside EEZs) were performed by R. V. "Prof. Siedlecki" (MIR, Gdynia). Thereby, a great number of leptocephali of anguilliform fish (mainly Anguilla anguilla) were caught, though the program was not especially designed for this purpose. Importance of the subadult eels as an extensively used valuable fishery resource, and the low extent of knowledge on the fate of larvae after leaving the hypothetical spawning area and before reaching the coastal shelves (cf. Tesch, 1980) induced us to analyse the collected material.

\section{MATERIAL AND METHODS}

At 109 stations (for complete list, see Bast \& Klinkhardt, 1987), hauls were made in depths between 5-1260 m. The depth of the hauls was measured by an echo sounder attached to the net. As gear a modified krill trawl net (mesh size of cod end $4.5 \mathrm{~mm}_{\text {; }}$ opening $15.7 \mathrm{~m}^{2}$ ) was used. Assuming a theoretical filtration rate of $100 \%$, at a towing speed of $2.5 \mathrm{kn}$, a water volume of $72691 \mathrm{~m}^{3}$ is filtered per hour. Unfortunately, the gear lacks an opening-closing mechanism, and therefore conclusions on exact depth of capture are impossible. Eel larvae were captured at 55 stations. For calculations of mean abundance, 17 additional trawls which yielded no eel larvae but which were performed in the depth range typically inhabited by leptocephali (above $250 \mathrm{~m}$ at night and 250-650 $\mathrm{m}$ at daytime; Tesch, 1980) were included. After capture, the leptocephali were preserved in seawater formalin $(4 \%)$. Measurements (nearest $0.1 \mathrm{~mm}$ ) and counts were 


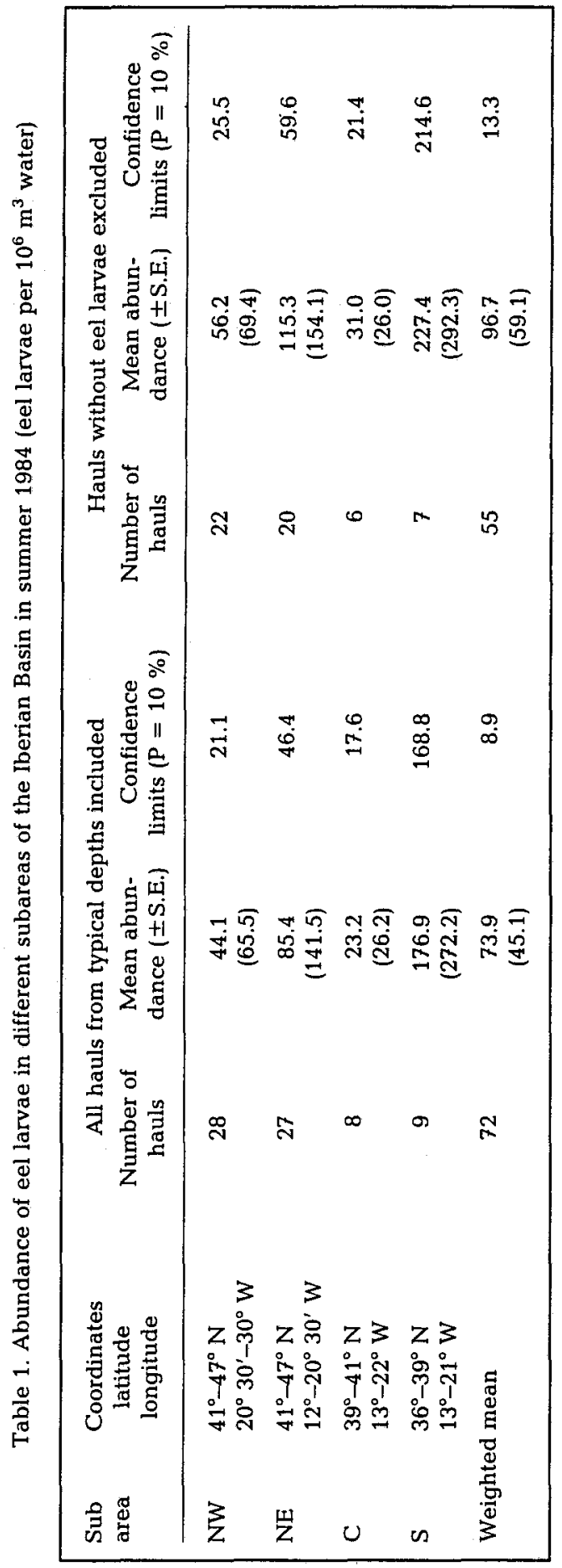


carried out in the laboratory, after 3 years storage, as part of the work for a diploma (Strehlow, 1988).

\section{RESULTS AND DISCUSSION}

The mean number of myomeres amounted to $114.82 \pm 1.64(\mathrm{~N}=363)$. This agrees well with the results of Schoth (1982) (114.68 $\pm 1.80 ; \mathrm{N}=895)$ and Kleckner \& McCleave (1985) (114.52 $\pm 0.047 ; \mathrm{N}=932$ ) but less with the data of Tesch \& Deelder (1978) $(114.00 \pm 1.89 ; N=30)$ and Kracht (1982) (113.9). Our value also coincides very closely with the mean number of vertebrae of European eels calculated by Boëtius (1980) $(114.62 \pm 0.011 ; \mathrm{N}=15854)$.

One specimen ( $68.7 \mathrm{~mm}$ total length; stn. $12: 37^{\circ} 53^{\prime} \mathrm{N} / 14^{\circ} 0.5^{\prime} \mathrm{W}$ ) showed only 107 myomeres and because, moreover, the number of myomeres to the third visible intestinal blood vessel amounted only to 44 , it had to be placed to Anguilla rostrata. The hitherto easternmost record of a larval American eel was a specimen of $70 \mathrm{~mm}$ total length from $49^{\circ} 43^{\prime} \mathrm{N} / 20^{\circ} 45^{\prime} \mathrm{W}$ (Kleckner \& McCleave, 1985). Schoth \& Tesch $(1981,1982)$ found $A$. rostrata larvae eastward until $52^{\circ} \mathrm{W}$. According to the number of vertebrae, approximately $0.13 \%$ of 15854 analysed eels from European waters proved to belong to $A$. rostrata (Harding, 1980).

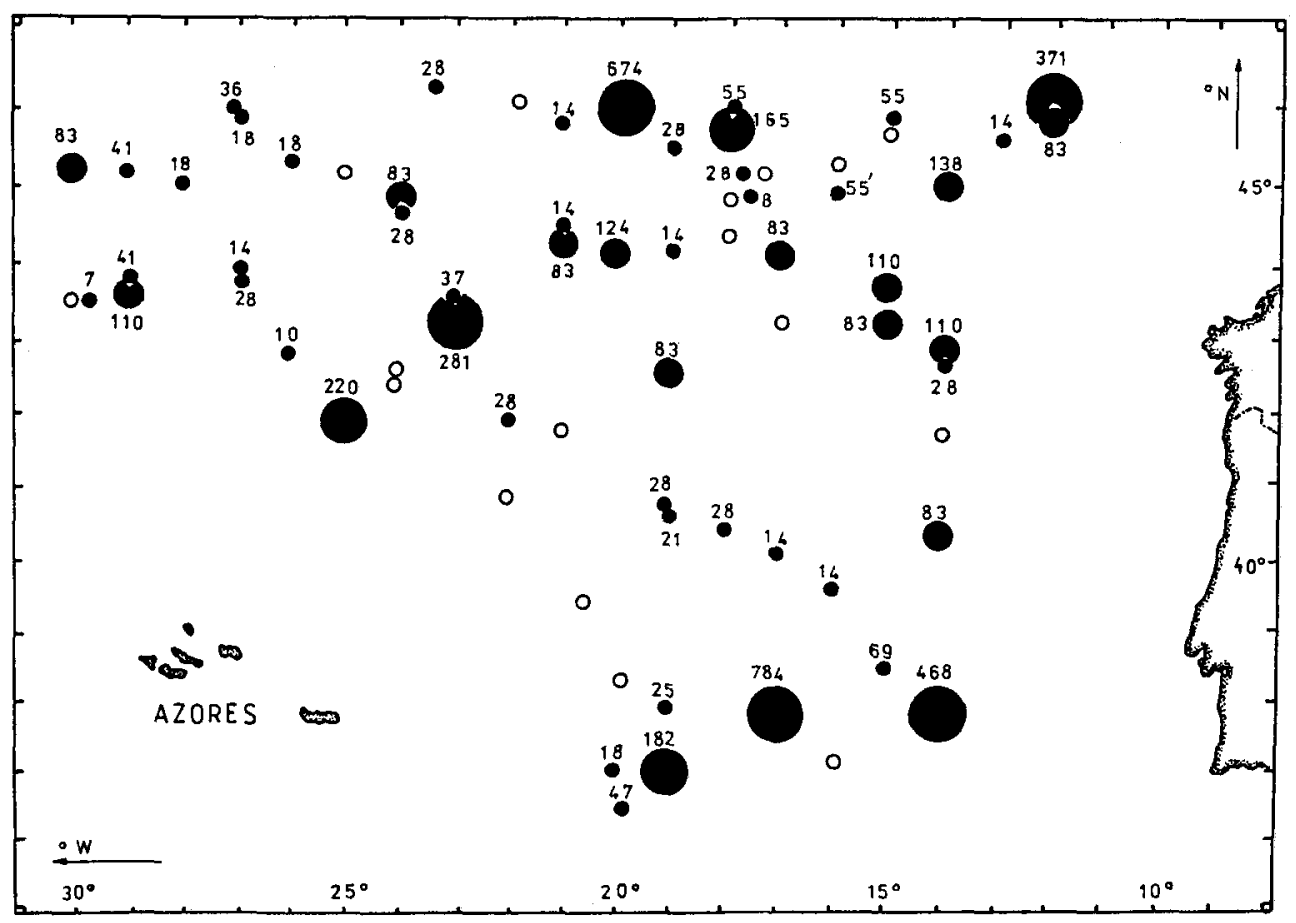

Fig. 1. Horizontal distribution of eel leptocephali from the Iberian Basin during summer 1984 (numbers $=$ larvae per $10^{6} \mathrm{~m}^{3} ;$ open circles $=$ stations without larvae) 
For the investigated area, a mean abundance of 74 larvae $/ 10^{6} \mathrm{~m}^{3}$ water was found (Table 1). If the unsuccessful hauls are disregarded, a mean of 97 specimens $/ 10^{6} \mathrm{~m}^{3}$ results. The horizontal pattern of abundances shows a high degree of patchiness (Fig. 1). If the investigation area is subdivided (Table 1), highest values occur in the southern subarea which seems to be separated from the northern part by a zone of low abundance. The mean abundance of eel larvae in the northeastern part of our investigation area was found to be nearly twice the value for the northwestern subarea. These results are difficult to interpret, unless we assume a migration of larvae from the southern to the northeastern subarea that increases in amount from west to east. However, evidence for this idea is lacking so far.

Around 3 months later (Nov./Dec. 1984), R. V. "Friedrich Heincke" made 29 hauls in the area from Biscay to Gibraltar, and a mean abundance of 94 larvae $/ 10^{6} \mathrm{~m}^{3}$ was found (Tesch et al., 1986). Our value for the northeastern subarea $\left(85\right.$ larvae $/ 10^{6} \mathrm{~m}^{3}$ ) agrees surprisingly well with this result. While our values may be underestimates due to the less appropriate fishing method, the mean abundance reported by Tesch et al. (1986) could,

Table 2. 3-year means of eel larvae abundance off the European continental shelf 1971-1985 (values compiled from data of Tesch (1980) and Tesch at al. $(1985,1986)$

\begin{tabular}{|ccc|}
\hline Period & $\begin{array}{c}\text { Mean abundance } \\
\left(\text { larvae/10 } \mathrm{m}^{3}\right)\end{array}$ & $\begin{array}{c}\text { Relative abundance } \\
(\%)\end{array}$ \\
\hline $1971-1973$ & 1099 & 100 \\
$1974-1976$ & 708 & 64 \\
$1977-1979$ & 559 & 51 \\
$1980-1982$ & 172 & 16 \\
$1983-1985$ & 105 & 10 \\
\hline
\end{tabular}

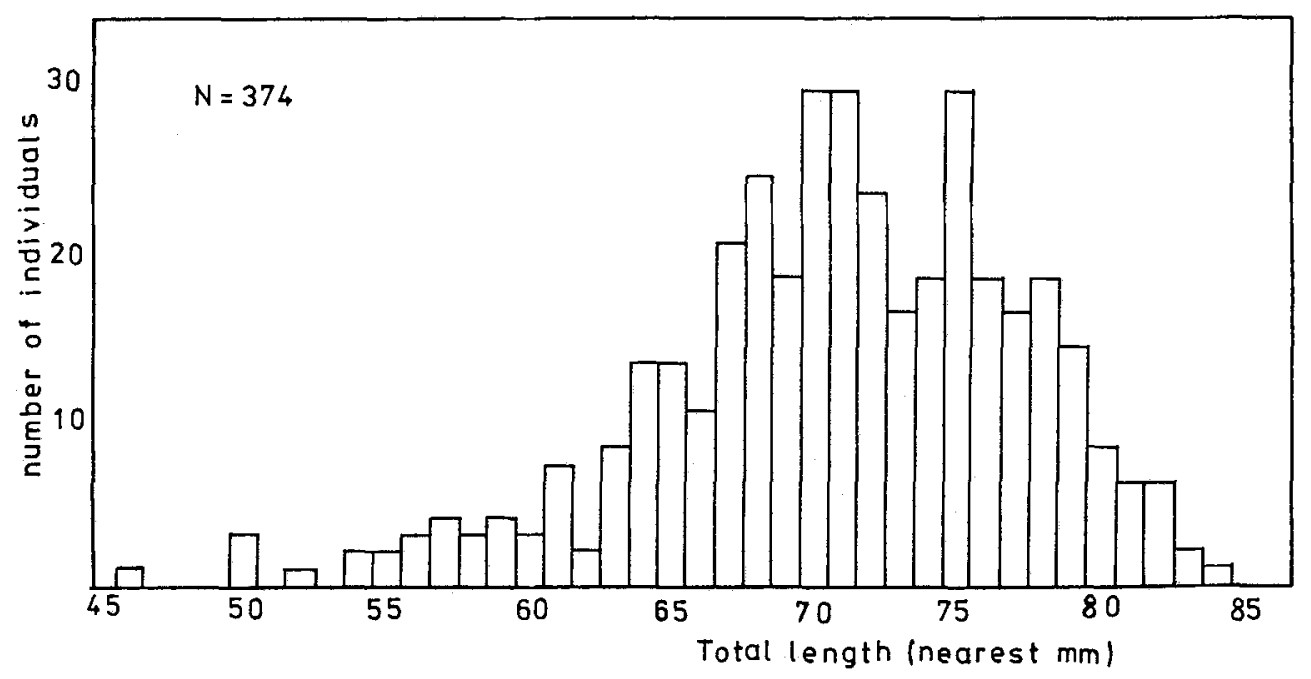

Fig. 2. Length frequency distribution of eel larvae 
on the other hand, represent an overestimate because of a crowding effect at the continental shelf. In any case, the close correspondence of both values confirms the validity of making conclusions on the general trends of larval abundance west of the European continental shelf from samples in the Biscay and adjacent regions as was done by Tesch $(1980)$ and Tesch et al. $(1985,1986)$. So it can be stated that the observed alarming decline of eel larvae abundance (Table 2) must be taken as valid for the whole European eel stock and should be reflected by further drastically decreasing commercial eel yields from European waters during coming years. Taking into account these perspectives, Tesch (1986) suggested placing the European eel on the "red lists" of endangered species and demanded measures to sustain and to promote natural eel reproduction. Our results also support this suggestion. Unfortunately, successful effort presupposes a joint action by several countries (e.g. restriction of catches especially of glass and silver eels; improvement of possibilities for unrestricted ana- and katadromous migration; restocking measures).

Measurement of total length of 374 larvae from 61 stations (including 5 stations from 1985) gave a mean of $70.74 \pm 6.46 \mathrm{~mm}$. The broad range of observed individual lengths (Fig. 2) must be interpreted as a representation of several age groups and/or of groups of larvae with differing life histories during migration. Utrecht \& Holleboom (1985) found that eel larvae from the mid and eastern North Atlantic showed 3-5, and glass eels from the Netherlands and France even 1-6 otolith growth zones. Length composition of our

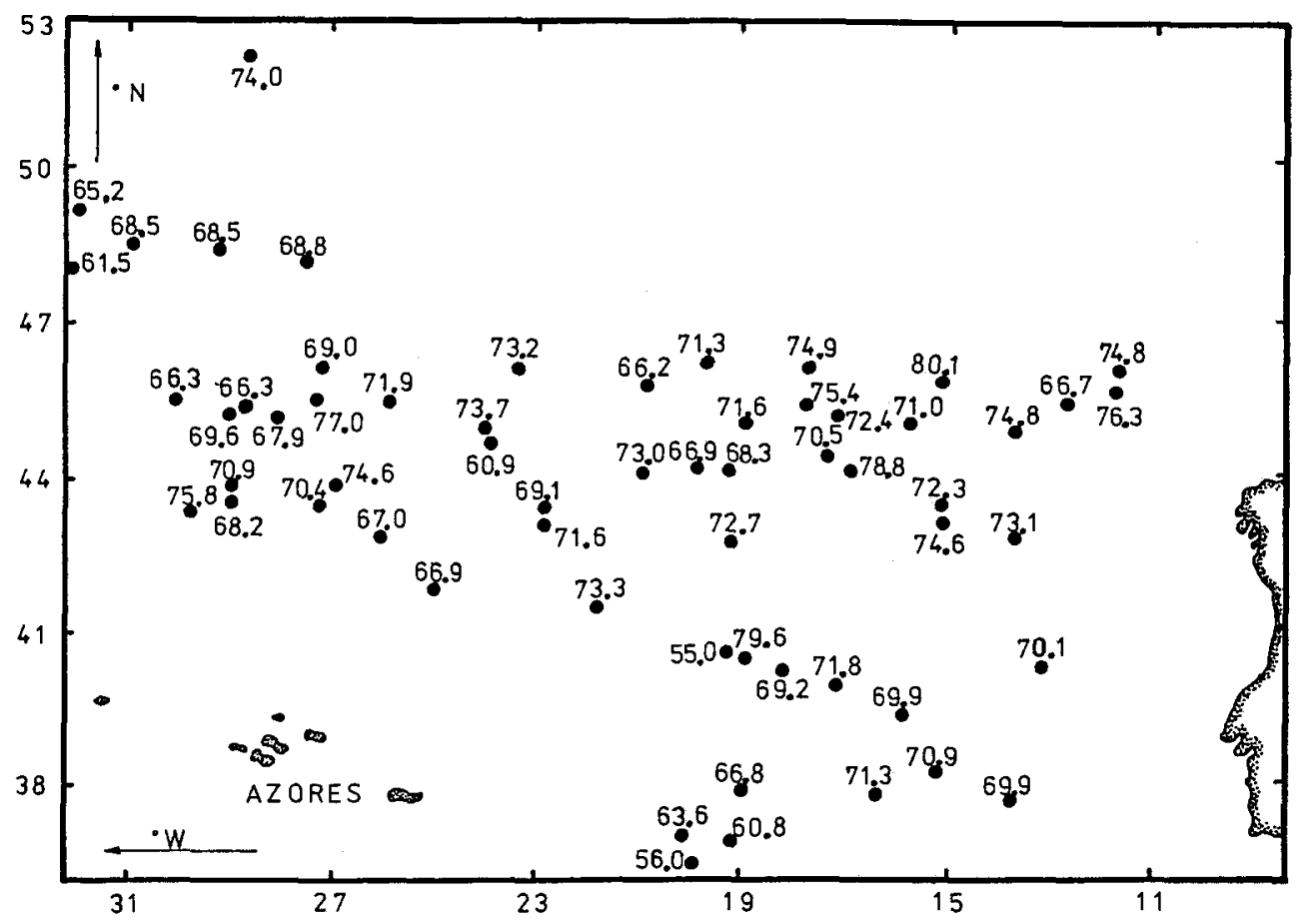

Fig. 3. Horizontal distribution of mean lengths of eel larvae from the Iberian Basin 
material is similar to that found by Tesch \{1980) off Great Britain and France (with total lengths between $62-80 \mathrm{~mm}$ ) and by Tesch \& Deelder (1978) at 11 stations between the Azores and northern Biscay (mean length $=68.3 \pm 8.72 \mathrm{~mm} ; \mathrm{N}=23$ ). Comparing the mean lengths of different stations, increasing values are recognizable from west to east

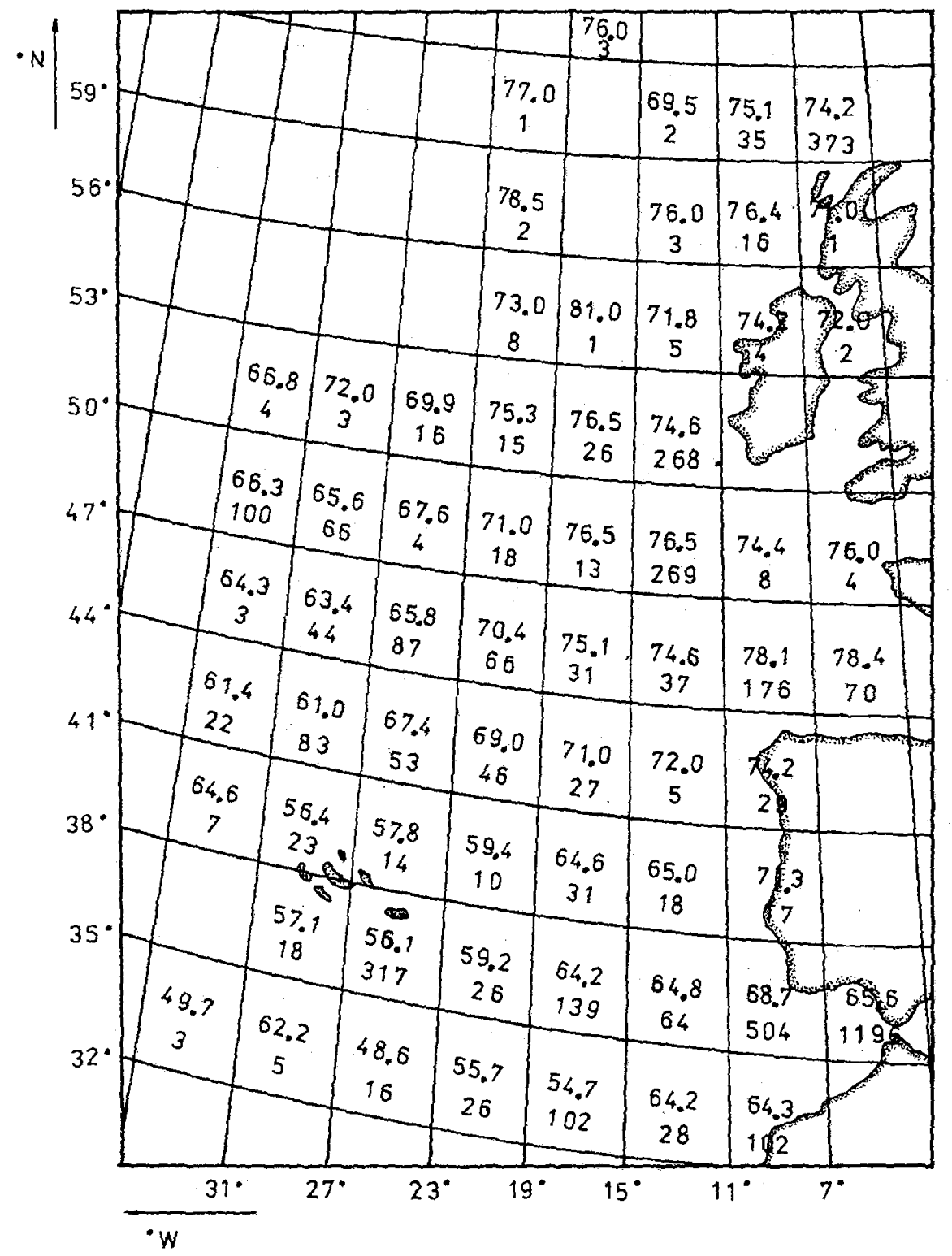

Fig. 4. Horizontal distribution of mean lengths of eel larvae from different areas of the Northeast Atlantic [data compiled from Boëtius \& Harding (1985) together with our values] upper number $=$ mean length; lower number $=$ number of values included 
and from south to north. It seems remarkable that, contrary to expectations (based on drift hypothesis), in the southern part of our investigation area significantly shorter (younger ?) specimens occur (Fig. 3). This phenomenon becomes even more evident when our data are combined with other published values from the Northeast Atlantic (Boëtius \& Harding, 1985) (Fig. 4).

Until recent years, most authors assumed that the migration of leptocephali from the spawning areas to the continental shelves is a passive drift by means of the Gulf Stream and North Atlantic Current (Schmidt, 1922, 1925; Bruun, 1963; Sinha \& Jones, 1967; Harden Jones, 1968; Tesch, 1973; Power \& McCleave, 1983; Boëtius, 1985; Kleckner \& McCleave, 1985; McCleave \& Kleckner, 1985, 1987; McCleave et al., 1987; Helfman et al., 1987). Doubts concerning this assumption first arose when animals of lower lengths and earlier development stages were found south of Gibraltar compared to those from northern stations (Tesch et al., 1979; Kracht, 1982; Tesch, 1983; Tesch et al., 1985, 1986). Likewise not consistent with the hypothesis of continuous passive drift is the observation of a great range in the number of growth zones in the otoliths of leptocephali and glass eels $(0+-10+)$ (Utrecht \& Holleboom, 1985; Moriarty, 1986). Also the occurrence of numerous larvae southwest of the Azores (an area not directly influenced by North Atlantic Current), higher abundances of older larvae (above $30 \mathrm{~mm}$ ) to the south of the Gulf Stream than within the Gulf Stream (Tesch et al., 1979; Kracht, 1982), and modern opinions on the circulation system of the North Atlantic (Köse et al., 1986; Krauss, 1986; Wenzel, 1986) support the hypothesis of an at least partly active migration of leptocephali towards the European shelf. The Azores Current may support this active migration and facilitate orientation. The 0+-larvae are distributed in a huge area (about 1.6 million $\mathrm{km}^{2}$ ) between $70^{\circ} \mathrm{W}$ and $50^{\circ} \mathrm{W}$ (e.g. Tesch et al., 1979; Schoth \& Tesch, 1981). If we continue to accept drift by Gulf Stream as the exclusive mechanism of larvae transport, we would have to explain how the larvae of the eastern part of the distributional range could cover the far distance (about $2500 \mathrm{~km}$ ) to the point of entrance into the Gulf Stream north of the Bahamas (Kleckner \& McCleave, 1982) or elsewhere without support of any suitable current. Beyond this, the larvae have also to overcome by some means the great gap between Gulf Stream and North Atlantic Current. The logical conclusion from all facts can only be the assumption of an active east-northeastward migration of a considerable portion of the larvae stock directly to the European shelf. The importance of the Gulf Stream as a transport medium has been greatly overrated up to this day.

Acknowledgement. We wish to express our gratitude to an unknown reviewer of the manuscript, who gave valuable hints and improved our English.

\section{LITERATURE CITED}

Bast, H.-D. \& Klinkhardt, M. B., 1987. Distribution of some mesopelagic fishes in the Iberian basin (eastern central North Atlantic). - Wiss. Z. Wilhelm-Pieck-Univ., Rostock 36, 57-62.

Boëtius, J., 1980. Atlantic Anguilla. A presentation of old and new data of total numbers of vertebrae with special reference to occurrence of Anguilla rostrata in Europe. - Dana 1, 93-112.

Boëtius, J., 1985. Greenland eels, Anguilla rostrata LeSueur. - Dana 4, 41-48.

Boëtius, J. \& Harding, E. F., 1985. List of Atlantic and Mediterranean Anguilla leptocephali: Danish material up to 1966. - Dana 4, 163-249.

Bruun, A. F., 1963. The breeding of the North-Atlantic freshwater-eels. - Adv. mar. Biol. 1, $137-169$. 
Harden Jones, F. R, 1968. Fish migration. Arnold, London, 325 pp.

Harding, E. F., 1980. Estimation of numbers of $A$, rostrata in European material (Appendix to Boëtius, 1980). - Dana 1, 111.

Helfman, G. S., Facey, D. E., Hales Jr., L. S: \& Bozeman Jr., E. L., 1987. Reproductive ecology of the American eel. - Am. Fish. Soc. Symp. 1, 1-15.

Kleckner, R. C. \& McCleave, J. D., 1982. Entry of migrating American eel leptocephali into the Gulf Stream system. - Helgoländer Meeresunters. 35, 329-339.

Kleckner, R. C. \& McCleave, J. D., 1985. Spatial and temporal distribution of American eel larvae in relation to North Atlantic Ocean current systems. - Dana 4, 67-92.

Köse, R. H., Price, J. F., Richardson, P. L. \& Zenk, W., 1986. A quasi-synoptic survey of the thermocline circulation and water mass distribution within the Canary Basin. - J. geogr. Res. 91, 9739-9748.

Kracht, R., 1982. On the geographic distribution and migrating of I- and II-group eel larvae as studied during the 1979 Sargasso Sea Expedition. - Helgoländer Meeresunters. 35, 321-327.

Krauss, W., 1986. The North-Atlantic current. - J. geogr. Res. 91, 5061-5074.

McCleave, J. D., 1986. Migration of Anguilla in the ocean: Signposts for adults! Signposts for leptocephali? - Proc. Multidisc. Workshop Mar. Anim. Orientation Migration, Tallahassee, Florida, 29-31 May 1986, 102-117.

McCleave, J. D. \& Kleckner, R. C., 1985. Oceanic migrations of Atlantic eels (Anguilla spp.): Adults and their offspring. - Contrib. mar. Sci. 27 (Suppl.), 316-337.

McCleave, J. D. \& Kleckner, R. C., 1987. Distribution of leptocephali of the catadromous Anguilla species in the western Sargasso Sea in relation to water circulation and migration. - Bull. mar. Sci. 41, 789-806.

McCleave, J. D., Kleckner, R. C. \& Castonguay, M., 1987. Reproductive sympatry of American and European eels and implications for migration and taxonomy. - Am. Fish. Soc. Symp. 1, 286-297.

Moriarty, C., 1986. Riverine migration of young eels Anguilla anguilla (L.). - Vie Millieu 36, 266.

Moriarty, C., 1987. Factors influencing recruitment of the Atlantic species of anguillid eels. - Am. Fish. Soc. Symp. 1, 483-491.

Power, J. H. \& McCleave, J. D., 1983. Simulation of the North Atlantic Ocean drift of Anguilla leptocephali. - Fish. Bull. U.S. 81, 483-500.

Schmidt, J., 1922. The breeding places of the eel. - Phil. Trans. R. Soc. 211, 179-208.

Schmidt, J., 1925. The breeding places of the eel. - A. Rep. Smithson. Instn 1924, 279-316.

Schoth, M., 1981. Taxonomic studies on the 0-group eel larvae (Anguilla spec.) caught in the Sargasso Sea in 1979. - Helgoländer Meeresunters. 35, 279-287.

Schoth, M., 1982. Taxonomic studies on the 0-group eel larvae (Anguilla spec.) caught in the Sargasso Sea in 1979. - C. M./ICES $M 9,1-23$.

Schoth, M. \& Tesch, F. W., 1981. Spatial distribution of the 0-group eel larvae (Anguilla spec.) 1979 in the Sargasso Sea. - C. M./ICES $M 8,1-23$.

Schoth, M. \& Tesch, F. W., 1982. Spatial distribution of 0-group eel larvae (Anguilla spec.) in the Sargasso Sea. - Helgoländer Meeresunters. 35, 309-320.

Sinha, V. R. P. \& Jones, J. W., 1967. The European freshwater eel. Univ. Press, Liverpool, 123 pp.

Strehlow, B., 1988. Fischereibiologische Untersuchungen an Leptocephali aus dem Nordatlantik zwischen den Azoren und der Iberischen Halbinsel. Dipl-Arb., Wilhelm-Pieck-Univ., Rostock, $110 \mathrm{pp}$.

Tesch, F. W., 1973. Der Aal. 1. Aufl. Parey, Hamburg, 300 pp.

Tesch, F. W., 1980. Occurrence of eel Anguilla anguilla larvae west of the European continental shelf, 1974-1977. - Environ. Biol. Fish 5, 185-190.

Tesch, F. W., 1983. Der Aal. 2. Aufl. Parey, Hamburg, 340 pp.

Tesch, F. W., 1986. Der Aal als Konkurrent von anderen Fischarten und von Krebsen. - Ost. Fisch. $39,5-20$.

Tesch, F. W. \& Deelder, C. L., 1978. Catches of metamorphosing eel larvae (Anguilla anguilla) between Europe and the Azores and some remarks on their development under laboratory conditions. - C. M./ICES $M 21,1-8$.

Tesch, F. W., Kracht, R., Schoth, M., Smith, D. G. \& Wegener, G., 1979. Report on the eel expedition of FRV "Anton Dohrn" and R. K. "Friedrich Heincke" to the Sargasso Sea 1979. - C. M./ICES M 6, 1-29. 
Tesch, F. W., Niermann, U. \& Plaga, A., 1985. Eel larvae (Anguilla anguilla) development stage and stock density differences in time and space off the west coast of Europe. - C. M./ICES M 32, 1-18.

Tesch, F. W., Niermann, U. \& Plaga, A., 1986. Differences in development stage and stock density of larval Anguilla anguilla off the west coast of Europe. - Vie Milieu 36, 255-260.

Utrecht, W. L. Van \& Holleboom, M. A., 1985. Notes on eel larvae (Anguilla anguilla Linnaeus, 1758) from the central and eastern North Atlantic and on glass eels from the European continental shelf. - Bijdr. Dierk. 55, 249-262.

Wenzel, M. K. C., 1986. Die mittlere Zirkulation des Nordatlantik auf der Grundlage klimatologischer hydrographischer Daten. - Ber. Inst. Meeresk., Kiel 157, 1-109. 